\title{
СХОЖІСТЬ НАСІННЯ КУКУРУДЗИ І МЕТОДИ ЇЇ ВИЗНАЧЕННЯ
}

М. Я. Кирпа, М. О. Стюрко

ДУ - Інститут сільського господарства степової зони НААН України

Наведено результати досліджень якості насіння гібридів кукурудзи та самозапилених ліній, взятих з партій з однаковою лабораторною схожістю. Встановлена значна різноякісність насіння за показниками його сили росту, схожості при холодному пророщуванні і польової, також врожайності навіть в межах категорії його кондиційності. Для встановлення різноякісності рекомендується метод холодного пророщування насіння, у якого рівень кореляції становить 0,72-0,81 порівняно 3 польовою схожістю. Метод пропонується використовувати у системі внутрішньогосподарського контролю якості насіння, а також стандартизувати з метою обов'язкового використання.

\section{Насіння кукурудзи, різноякісність, схожість, метод визначення}

Схожість $є$ основним показником якості насіння, який всебічно характеризує його посівну придатність. Зі схожістю значним чином пов'язаний ріст і розвиток рослин, їх продуктивність, врожайність. На прикладі цілого ряду культур встановлено, що внаслідок підвищення польової схожості на $1 \%$ врожайність може збільшуватись на 1-2 \% [1]. Встановлено також, що приріст врожаю, який пов'язаний зі схожістю, забезпечується не тільки кількісно - за рахунок оптимальної густоти рослин, але і якісно - за рахунок поліпшення їх фізіолого-біологічного стану, особливо на початкових стадіях росту і розвитку [2].

Як показує аналіз проведених досліджень та публікацій, існують різні способи визначення схожості насіння за допомогою прямих та непрямих методів [3-5]. До прямих методів відносяться ті, які засновані на пророщуванні насіння, оцінці його кількісних та якісних показників, до непрямих за допомогою побічних ознак - забарвленням живого зародку, ступенем електропровідності тощо.

Методи оцінки схожості насіння можна розділити на чинні та додаткові. До чинних належать методи визначення схожості сільськогосподарських культур за ДСТУ 4138-2002, відповідно до яких схожість розуміється як здатність насіння до максимального проростання в створених для цього оптимальних умовах. Звідси і основний недолік методу, який полягає в тому, що в оптимальних умовах може проростати різне насіння, у тому

(C) М. Я. Кирпа, М. О. Стюрко. 2012.

ISSN 0582-5075. Селекція і насінництво. 2012. Випуск 102. 
числі чимось ушкоджене, або неповноцінне і тому нездатне до проростання в більш жорстких польових умовах.

Додаткові методи дозволяють глибше оцінювати якість насіння, вони в більшій мірі пов'язані з його польовою схожістю і врожайними властивостями. Серед додаткових методів найчастіше застосовують визначення сили росту та холодне пророщування.

Особливо важливе значення відіграють додаткові методи для оцінки якості насіння тих культур, що можуть мати розтягнутий період між сівбою i сходами в залежності від погодно-кліматичних умов. В першу чергу це стосується кукурудзи, для неї такий період може тривати від 9 до 30 днів, залежно від того, яка складається температура і вологість грунту. Застосування додаткових методів дозволяє визначити потенційну стійкість насіння в різних умовах проростання, а також в певній мірі спрогнозувати його польову схожість.

Значення додаткових методів зростає в зв’язку з низькими врожайними властивостями насіння, яке зараз готується до сівби. Нерідко трапляється так, що насіння є кондиційним і має відповідну лабораторну схожість, але після сівби формує низьку польову схожість, від чого недоотримується врожай зерна на товарних площах.

Незважаючи на важливість методів, їх порівняльне вивчення є недостатнім, що не дозволяє вибрати найбільш оптимальні методи залежно від різноякісності насіння та особливостей певної культури.

Метою роботи було дослідження процесу пророщування гібридів i самозапилених ліній кукурудзи за допомогою чинних та додаткових методів, встановлення кореляції між лабораторною і польовою схожістю, визначення найбільш ефективного методу пророщування насіння.

Методика досліджень. Досліджували такі методи пророщування насіння - стандартний за ДСТУ 4138-2002, холодне пророщування і силу росту [6-8]. Основні параметри методів наведено в таблиці 1. Насіння, що вивчалось у лабораторних дослідах, висівали на ділянки, де визначали польову схожість і врожайність зерна. Польові досліди виконували згідно методики закладки і проведення дослідів з кукурудзою [9].

Результати досліджень та обговорення. У дослідах отримували різні показники проростання насіння залежно від методів його пророщування (табл. 2). Схожість була найвищою тоді, коли застосовували метод ДСТУ, а найнижчою - при холодному пророщуванні. При цьому схожість насіння самозапилених ліній знижувалась у більшій мірі порівняно 3 гібридами. Сила росту хоча і займала проміжне місце між різними методами, але була значно ближчою до показників стандартного методу пророщування насіння.

Показники проростання насіння значно коливались залежно як від пророщування так і різноякісності гібридів і ліній кукурудзи. Наприклад, коливання схожості насіння гібридів при стандартному пророщуванні складало 92-98\%, сили росту 90-95\%, схожості при холодному пророщуванні 75-88\%. 
Таблиця 1

Характеристика різних методів пророщування насіння кукурудзи

\begin{tabular}{|c|c|c|c|c|c|}
\hline \multirow[b]{2}{*}{ Метод } & \multicolumn{4}{|c|}{ Характеристика } & \multirow[b]{2}{*}{$\begin{array}{c}\text { Показники } \\
\text { проростання }\end{array}$} \\
\hline & $\begin{array}{c}\text { ложе для } \\
\text { проро- } \\
\text { щування }\end{array}$ & $\begin{array}{c}\text { розмі- } \\
\text { щення } \\
\text { насіння }\end{array}$ & $\begin{array}{l}\text { темпе- } \\
\text { ратура, } \\
{ }^{\circ} \mathrm{C}\end{array}$ & $\begin{array}{c}\text { трива- } \\
\text { лість, } \\
\text { діб } \\
\end{array}$ & \\
\hline \begin{tabular}{|l|} 
Пророщування \\
по ДСТУ
\end{tabular} & $\begin{array}{l}\text { пісок } \\
\text { папір }\end{array}$ & $\begin{array}{l}\mathrm{H} \Pi \\
\text { в } \Phi \\
\end{array}$ & 25 & $7(10)$ & число сходів \\
\hline Сила росту & $\begin{array}{l}\text { пісок } \\
\text { папір }\end{array}$ & $\begin{array}{l}\text { вП } \\
\text { вФ }\end{array}$ & $\begin{array}{l}20 \\
25\end{array}$ & 10 & $\begin{array}{l}\text { число сходів, маса } \\
\text { ростків, кількість } \\
\text { сильних ростків }\end{array}$ \\
\hline $\begin{array}{l}\text { Холодне про- } \\
\text { рощування }\end{array}$ & земля & в3 & $\begin{array}{l}8-10 \\
18-22\end{array}$ & 14 & $\begin{array}{c}\text { число сходів, маса } \\
\text { ростків, кількість } \\
\text { сильних ростків }\end{array}$ \\
\hline
\end{tabular}

нП - на піску, вП - в піску, вФ - в папері, в3 - в землі

Таблиця 2

Показники проростання насіння гібридів і самозапилених ліній кукурудзи залежно від методу пророщування, 2009-2012 pр.

\begin{tabular}{|c|c|c|c|c|c|}
\hline \multirow{3}{*}{ Гібрид, лінія } & \multirow{3}{*}{$\begin{array}{c}\text { Метод } \\
\text { проро- } \\
\text { щування }\end{array}$} & \multicolumn{4}{|c|}{ Показники проростання } \\
\hline & & \multirow{2}{*}{$\begin{array}{c}\text { енергія } \\
\text { росту, } \\
\%\end{array}$} & \multicolumn{2}{|c|}{ схожість, \% } & \multirow{2}{*}{$\begin{array}{c}\text { маса } \\
\text { ростків, } \\
\Gamma\end{array}$} \\
\hline & & & середне & $\begin{array}{c}\text { межі } \\
\text { коливань }\end{array}$ & \\
\hline $\begin{array}{l}\text { Гібриди: } \\
\text { Дніпровський } 181 \mathrm{CB}, \\
\text { Кремінь } 200 \mathrm{CB}, \\
\text { Кадр } 267 \mathrm{MB}, \\
\text { Любава } 279 \text { МВ, } \\
\text { Розівський } 311 \text { СВ } \\
\end{array}$ & $\begin{array}{l}1 \\
2 \\
3\end{array}$ & $\begin{array}{c}93,0 \\
- \\
78,7\end{array}$ & $\begin{array}{l}95,3 \\
92,0 \\
85,0\end{array}$ & $\begin{array}{l}92-98 \\
90-95 \\
75-88\end{array}$ & $\begin{array}{c}- \\
32,0 \\
31,2\end{array}$ \\
\hline \multicolumn{2}{|c|}{$\mathrm{HIP}_{05}$} & $1,3-1,4$ & \multicolumn{3}{|c|}{$0,6-0,7$} \\
\hline $\begin{array}{l}\text { Лінії: } \\
\text { ДК 205/710, ДК 276, } \\
\text { ДК 366, ДК 437, } \\
\text { ДК 744 }\end{array}$ & $\begin{array}{l}1 \\
2 \\
3\end{array}$ & $\begin{array}{c}86,5 \\
- \\
67,5\end{array}$ & $\begin{array}{l}92,7 \\
87,5 \\
76,5\end{array}$ & $\begin{array}{l}92-94 \\
84-90 \\
66-78\end{array}$ & $\begin{array}{c}- \\
23,5 \\
21,8\end{array}$ \\
\hline $\mathrm{HII}$ & & $1-1,2$ & & $0,3-0,5$ & \\
\hline
\end{tabular}

1 - метод ДСТУ, 2 - сила росту, 3 - холодне пророщування

Коливання показників проростання насіння самозапилених ліній становило, відповідно, 92-94, 84-90 і 66-78\%. Маса ростків також змінювалась залежно від методу пророщування і різноякісності сортозразка кукурудзи. При цьому слід наголосити, що за різними методами пророщували насіння кондиційне, зі схожістю 92-98\%. У насіння некондиційного межі коливань показників проростання значно розширюються, особливо при застосуванні методу холодного пророщування. 
В дослідах виявлено також особливості проростання кондиційного насіння. Насіння для досліду підбирали таке, яке характеризувалось однаковою кондиційною схожістю і зберігалось в тотожних умовах, всього по кожному гібриду чи лінії було сформовано таким чином по дві партії.

При досліджуваних методах пророщування насіння 3 двох партій проростало по-різному, незважаючи на однакову лабораторну схожість (табл. 3).

Таблиця 3

Показники проростання різних партій насіння гібридів і самозапилених ліній кукурудзи при різних методах пророщування, 2010 - 2012 pp.

\begin{tabular}{|c|c|c|c|c|c|}
\hline \multirow[b]{2}{*}{ Гібрид, лінія } & \multirow[b]{2}{*}{$\begin{array}{c}\text { Партія } \\
\text { насіння }\end{array}$} & \multirow[b]{2}{*}{$\begin{array}{c}\text { Метод } \\
\text { пророщування }\end{array}$} & \multicolumn{3}{|c|}{ Показники проростання } \\
\hline & & & $\begin{array}{c}\text { енергія } \\
\text { росту, } \\
\%\end{array}$ & $\begin{array}{c}\text { схожість, } \\
\%\end{array}$ & $\begin{array}{c}\text { маса } \\
\text { ростків, } \\
\Gamma\end{array}$ \\
\hline \multirow{6}{*}{$\begin{array}{c}\text { Дніпровський } \\
181 \text { СВ }\end{array}$} & \multirow{3}{*}{ перша } & 1 & 97 & 98 & - \\
\hline & & 2 & - & 95 & 33,4 \\
\hline & & 3 & 84 & 88 & 32,7 \\
\hline & \multirow{3}{*}{ друга } & 1 & 96 & 98 & - \\
\hline & & 2 & - & 95 & 31,0 \\
\hline & & 3 & 80 & 83 & 29,6 \\
\hline \multirow{6}{*}{$\begin{array}{c}\text { Розівський } \\
311 \text { СВ }\end{array}$} & \multirow{3}{*}{ перша } & 1 & 93 & 95 & - \\
\hline & & 2 & - & 92 & 34,0 \\
\hline & & 3 & 80 & 85 & 35,8 \\
\hline & \multirow{3}{*}{ друга } & 1 & 90 & 95 & - \\
\hline & & 2 & - & 91 & 34,9 \\
\hline & & 3 & 74 & 81 & 30,3 \\
\hline \multirow{6}{*}{ ДК 276} & \multirow{3}{*}{ перша } & 1 & 86 & 88 & - \\
\hline & & 2 & - & 85 & 22,7 \\
\hline & & 3 & 71 & 76 & 19,6 \\
\hline & \multirow{3}{*}{ друга } & 1 & 81 & 88 & - \\
\hline & & 2 & - & 84 & 20,5 \\
\hline & & 3 & 60 & 65 & 16,3 \\
\hline \multirow{6}{*}{ ДК 744} & \multirow{3}{*}{ перша } & 1 & 90 & 92 & - \\
\hline & & 2 & - & 90 & 33,8 \\
\hline & & 3 & 75 & 82 & 32,0 \\
\hline & \multirow{3}{*}{ друга } & 1 & 85 & 92 & - \\
\hline & & 2 & - & 88 & 26,5 \\
\hline & & 3 & 70 & 78 & 26,1 \\
\hline
\end{tabular}

Наприклад, при пророщуванні за методом ДСТУ насіння гібридів чи самозапилених ліній, відібране 3 двох партій, мало однакову схожість: у гібрида Дніпровський $181 \mathrm{CB}$ становила $98 \%$, Розівський $311 \mathrm{CB}-95 \%$, лінії ДК $276-88$ \%, ДК $744-92 \%$. 
При холодному пророщуванні схожість насіннявідібраного 3 двох партій, була зовсім іншою: по-перше, вона знижувалась порівняно зі стандартним пророщуванням на 10-15 \% (гібриди), 10-23 (самозапильні лінії); по-друге, коливання схожості між різними партіями складало 5-9 \% (гібриди) і 4-11\% (самозапилені лінії). Зниження схожості ще супроводжувалось одночасним зменшенням маси ростків на 3,1-5,5 г (гібриди) і 3,3-5,9 г (самозапилені лінії). Отже виходить, що партії, рівноцінні по схожості за чинною оцінкою (ДСТУ 4138), можуть бути досить різноякісними, що проявляється у польовій схожості і врожайних властивостях насіння. Як показали наші досліди, виявити таку різноякісність можна за допомогою методу холодного пророщування.

Для вивчення характеру різноякісності було проведено лабораторнопольовий дослід, який включав різні методи пророщування насіння. Насамперед для досліду були сформовані, виходячи зі стандартного пророщування, різні категорії насіння, зі схожістю 87-91, 92-95, 96-100 \%. По кожній категорії насіння визначали силу росту, показники холодного пророщування, польової схожості і врожайності зерна.

Встановлено різну якість насіння залежно від категорії його схожості, у тому числі того, яке було кондиційним (табл. 4). Так, між категоріями кондиційного насіння гібридів (схожість 92-100\%) різниця по силі росту становила 3-5 \%, при холодному пророщуванні - 5-15\%, польовій схожості - 4-12\%. Між категоріями самозапиленої лінії різниця за цими показниками складала 5, 7-10 \% і 7-9 \% відповідно. Категорія насіння зі схожістю 87$91 \%$ поступалась категорії 92-95\%, таким чином: по силі росту - на 2-6 \%, по схожості при холодному пророщуванні на 7-15\%, польовій на 6-14 \% (гібриди) та відповідно 7, 5-10 і 7-8 \% (самозапилена лінія).

При цьому результати по силі росту, холодному пророщуванні і польовій схожості значно коливались і переходили межі окремих градацій. Наприклад, категорія насіння зі схожістю 92-95 \% характеризувалась показниками, які дещо співпадали з іншими категоріями зі схожістю 8791 i $96-100 \%$.

Різна якість насіння, віднесеного до окремих категорій, впливала на його врожайні властивості. Так, від насіння з категорією схожості 87$91 \%$ врожайність зерна гібридів знижувалась на 0,24-1,60 т/га, самозапиленої лінії - на 0,26-0,66 т/га порівняно з насінням категорій 92-95 і 96-100\%. Навіть серед категорій кондиційного насіння продуктивність була різною, від насіння зі схожістю 96-100\% врожайність гібридів підвищувалась на 0,41-1,01 т/га, лінії - на 0,22-0,30 т/га порівняно 3 насінням категорії 92-95\%.

У цілому, за рахунок більш якісного насіння врожай зерна гібридів кукурудзи збільшувався на 14,7-20,6 \%, самозапиленої лінії - на 20,7$24,4 \%$.

Ці дані свідчать про особливості, які слід враховувати при користуванні таким методом лабораторного пророщування, як чинний стандартизований за ДСТУ. 
Таблиця 4

Різноякісність насіння кукурудзи залежно від категорії його схожості, 2010-2012 pp.

\begin{tabular}{|c|c|c|c|c|c|}
\hline \multirow{3}{*}{$\begin{array}{l}\text { Гібрид, } \\
\text { лінія }\end{array}$} & \multirow{3}{*}{$\begin{array}{l}\text { Катего- } \\
\text { рія схо- } \\
\text { жості за } \\
\text { ДСТУ, \% }\end{array}$} & \multicolumn{4}{|c|}{ Показники якості насіння } \\
\hline & & \multirow[b]{2}{*}{$\begin{array}{c}\text { сила } \\
\text { рос- } \\
\text { ту, \% }\end{array}$} & \multicolumn{2}{|c|}{ схожість, \% } & \multirow[b]{2}{*}{$\begin{array}{c}\text { урожай- } \\
\text { ність зер- } \\
\text { на, т/га }\end{array}$} \\
\hline & & & $\begin{array}{c}\text { холодне } \\
\text { пророщу- } \\
\text { вання }\end{array}$ & польова & \\
\hline \multirow{3}{*}{$\begin{array}{l}\text { Дніпровсь- } \\
\text { кий } 181 \mathrm{CB}\end{array}$} & $87-91$ & $84-90$ & $61-71$ & $62-73$ & $4,02-4,90$ \\
\hline & $92-95$ & $87-92$ & $68-85$ & $68-85$ & $4,63-5,10$ \\
\hline & $96-100$ & $90-96$ & $80-91$ & $80-93$ & $5,07-5,63$ \\
\hline \multicolumn{3}{|l|}{$\mathrm{HIP}_{05}$} & $2,1-2,4$ & $18-0,19$ & \\
\hline \multirow{3}{*}{$\begin{array}{l}\text { Кадр } \\
267 M B\end{array}$} & $87-91$ & $82-91$ & $61-75$ & $58-78$ & $4,81-5,48$ \\
\hline & $92-95$ & $88-94$ & $68-90$ & $71-88$ & $5,08-5,90$ \\
\hline & $96-100$ & $93-98$ & $82-95$ & $80-92$ & $5,65-6,50$ \\
\hline \multicolumn{3}{|l|}{$\mathrm{HIP}_{05}$} & $1,8-2,1$ & $0,2-0,23$ & \\
\hline \multirow{3}{*}{$\begin{array}{l}\text { Любава } \\
\text { 279МВ }\end{array}$} & $87-91$ & $85-90$ & $60-70$ & $60-72$ & $4,70-5,50$ \\
\hline & $92-95$ & $87-92$ & $67-80$ & $68-81$ & $5,11-5,93$ \\
\hline & $96-100$ & $90-95$ & $79-87$ & $75-88$ & $5,52-6,49$ \\
\hline \multicolumn{3}{|l|}{$\mathrm{HIP}_{05}$} & $1,9-2,4$ & $0,19-0,23$ & \\
\hline \multirow{3}{*}{$\begin{array}{l}\text { Розівський } \\
\text { 311СВ }\end{array}$} & $87-91$ & $85-90$ & $58-70$ & $56-74$ & $5,01-5,60$ \\
\hline & $92-95$ & $87-94$ & $65-82$ & $70-85$ & $5,25-6,04$ \\
\hline & $96-100$ & $90-99$ & $80-90$ & $79-90$ & $5,87-7,05$ \\
\hline \multicolumn{3}{|l|}{$\mathrm{HIP}_{05}$} & $2,0-2,2$ & $0,21-0,24$ & \\
\hline \multirow{3}{*}{ ДК 276} & $87-91$ & $78-86$ & $50-70$ & $51-68$ & $1,84-2,05$ \\
\hline & $92-95$ & $85-93$ & $60-75$ & $69-75$ & $2,10-2,41$ \\
\hline & $96-100$ & $90-95$ & $70-82$ & $68-82$ & $2,32-2,71$ \\
\hline \multicolumn{3}{|l|}{$\mathrm{HIP}_{05}$} & $2,1-2,5$ & $0,15-0,16$ & \\
\hline
\end{tabular}

За його допомогою можна встановити максимальну спроможність насіння до пророщування в ідеальних для цього умовах, але метод не визначає посівну придатність насіння залежно від його різноякісності.

Причинами такої різноякісності можуть бути як агробіологічні властивості насіння, так і його техніко-технічні особливості збирання, обробки та зберігання.

Як показали наші досліди, до більш точних методів визначення схожості та посівної придатності насіння кукурудзи відноситься холодне пророщування, яке включає перемінний температурний режим та використання грунту в якості субстрату для проростання. У дослідах схожість, визначена таким методом, наближалась до польової, особливо якщо насіння було різноякісне, ушкоджене, або ж довго зберігалось.

Підтвердженням цього $є$ рівень кореляції між польовою схожістю та схожістю, визначеною різними методами лабораторного пророщування насіння. Виявлено, що рівень кореляції був найбільшим при холодному 
пророщуванні і становив 0,72-0,81 для гібридів і самозапилених ліній кукурудзи (табл. 5). Найменша кореляція зафіксована у випадку пророщування за чинним методом ДСТУ в межах 0,35-0,37. Встановлено також, що самозапилені лінії мають дещо нижчий рівень кореляції у порівнянні з гібридами, оскільки в польових умовах менш стійкі і значно змінюють схожість залежно від своєї якості.

Таблиця 5

Кореляція між лабораторною і польовою схожістю насіння кукурудзи

\begin{tabular}{|l|c|c|}
\hline \multicolumn{1}{|c|}{ Гібрид, лінія } & $\begin{array}{c}\text { Метод визначення } \\
\text { схожості }\end{array}$ & $\begin{array}{c}\text { Рівень } \\
\text { кореляції }\end{array}$ \\
\hline Гібриди: & & \\
Дніпровський 181 СВ, & 1 & 0,37 \\
Кремінь 200 СВ, & 2 & 0,58 \\
Кадр 267 МВ, & 3 & 0,81 \\
Любава 279 МВ, & & \\
Розівський 311 СВ & 1 & 0,35 \\
\hline Лінії: & 2 & 0,50 \\
ДК 205/710, ДК 276, ДК 366, & 3 & 0,72 \\
ДК 437, ДК 744 & & \\
\hline
\end{tabular}

У методичному плані холодне пророщування забезпечує досить високу достовірність аналізу. Наприклад, коливання схожості між окремими повтореннями відповідає допустимим нормам, встановленим чинним ДСТУ (табл. 6). Отже, при правильному виконанні і додержанні необхідних умов пророщування метод холодного пророщування гарантує точну і об'єктивну оцінку насіння.

Висновки. Встановлено значну різноякісність насіння гібридів і самозапилених ліній кукурудзи залежно від категорії його лабораторної схожості. Різноякісність визначалась за основними показниками посівних $\mathrm{i}$ врожайних властивостей насіння - його силою росту, схожістю при холодному пророщуванні та польовою, а також врожайністю. Виявлено, що навіть у категорії кондиційного насіння гібридів, тотожного за всіма параметрами та зі схожістю 92-100 \%, сила росту коливалась в межах 3-5\%, схожість при холодному пророщуванні - 5-15\%, польова $-4-12 \%$, врожайність зерна - 0,41-1,01 т/га, у ліній - відповідно 5, 7-10 і 7-9 \% та 0,220,30 т/га. Категорія зі схожістю 87-91 \% значно поступалася за показниками посівних і врожайних властивостей насіння як у гібридів, так і самозапилених ліній.

Для виявлення різноякісності та встановлення посівної придатності насіння гібридів і ліній кукурудзи рекомендується метод холодного пророщування, рівень кореляції якого до польової схожості становить $0,72-0,81$. 
Таблиця 6

Коливання схожості насіння гібридів і самозапилених ліній кукурудзи, визначеної різними методами, 2011-2012 pp.

\begin{tabular}{|c|c|c|c|c|c|c|c|c|}
\hline \multirow[b]{2}{*}{ Гібрид, лінія } & \multirow[b]{2}{*}{$\begin{array}{c}\text { Метод } \\
\text { пророщу- } \\
\text { вання }\end{array}$} & \multicolumn{5}{|c|}{$\begin{array}{c}\text { Схожість насіння за } \\
\text { повтореннями }\end{array}$} & \multicolumn{2}{|c|}{$\begin{array}{c}\text { Відхилення } \\
\text { від } \\
\text { середнього }\end{array}$} \\
\hline & & 1 & 2 & 3 & 4 & 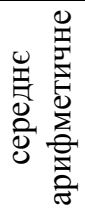 & 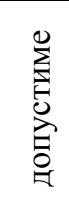 & 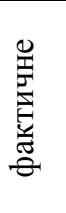 \\
\hline \multirow{3}{*}{ Дніпровський 181CВ } & 1 & 92 & 100 & 98 & 96 & 96 & \pm 4 & 4 \\
\hline & 2 & 92 & 94 & 96 & 90 & 94 & \pm 5 & 4 \\
\hline & 3 & 86 & 82 & 83 & 88 & 85 & \pm 7 & 3 \\
\hline \multirow{3}{*}{ Розівський $311 \mathrm{CB}$} & 1 & 96 & 92 & 89 & 98 & 94 & \pm 5 & 5 \\
\hline & 2 & 94 & 92 & 88 & 86 & 90 & \pm 6 & 4 \\
\hline & 3 & 84 & 80 & 78 & 88 & 83 & \pm 7 & 5 \\
\hline \multirow{3}{*}{ ДК 276} & 1 & 92 & 94 & 96 & 87 & 92 & \pm 5 & 5 \\
\hline & 2 & 86 & 80 & 88 & 82 & 84 & \pm 7 & 4 \\
\hline & 3 & 69 & 76 & 74 & 72 & 76 & \pm 8 & 7 \\
\hline \multirow{3}{*}{ ДК 744} & 1 & 88 & 96 & 94 & 92 & 93 & \pm 5 & 5 \\
\hline & 2 & 88 & 90 & 86 & 80 & 86 & \pm 7 & 6 \\
\hline & 3 & 80 & 72 & 74 & 78 & 76 & \pm 8 & 4 \\
\hline
\end{tabular}

Метод може застосовуватись в системах державного та внутрішньогосподарського контролю для додаткової оцінки якості насіннєвого матеріалу.

\section{Список використаних джерел}

1. Ижик Н. К. Полевая всхожесть семян / Н. К. Ижик - Киев: Урожай, 1976. $-190 \mathrm{c}$.

2. Кирпа М. Я. Ознаки та показники якості насіння гібридів кукурудзи / М. Я. Кирпа, Н. О. Пащенко // Бюл. Інст. зерн. госп-ва, 2011. - № 40. C. $14-20$.

3. Насінництво й насіннєзнавство польових культур / [За ред. М. М. Гаврилюка]. - К.: Аграрна наука, 2007. - 216 с.

4. Гриценко В. В. Совершенствование методики проращивания семян при определении всхожести / В. В. Гриценко, В. А. Дмитриева, П. Д. Бугаев // Селекция и семеноводство, - 1987. - № 2. - С. 42-43.

5. Матющенко Л. В. Всхожесть и урожайные свойства семян зерновых культур / Л. В. Матющенко, Б. А. Весна // Селекция и семеноводство, 1990. - № 3. - C. 49-51.

6. Насіння сільськогосподарських культур. Метод визначання якості: ДСТУ 4136-2002 [Чинний від 2004-01-01]. - К.: Держспоживстандарт України, 2003. - 173 с. - (Держспоживстандарт України). 
7. Методика изучения силы роста семян полевых культур; подгот. И. Г. Строна. - М.: Колос, 1964. - 24 с.

8. Репин А. Н. Метод холодного проращивания семян кукурузы / А. Н. Репин, А. И. Науменко // Бюл. ВНИИ кукурузы, 1972. - Вып. 5-6. - С. 55-58.

9. Методика проведеня польових дослідів з кукурудзою: методичні рекомендації [підгот. Є. М. Лебідь, В. С. Циков, Ю. М. Пащенко [та ін.]. - Дніпропетровськ, 2008. - 27 с.

Приведены результаты исследований качества семян гибридов кукурузы и самоопылённых линий, взятых из партий с одинаковой лабораторной всхожестью. Установлена значительная разнокачественность семян по показателям их силы роста, всхожести при холодном проращивании и полевой, также урожайности даже в пределах категории их кондиционности. Для установления разнокачественности рекомендуется метод холодного проращивания семян, у которого уровень корреляции составляет 0,72-0,81 по сравнению с полевой всхожестью. Метод предлагается использовать в системе внутрихозяйственного контроля качества семян, а также стандартизировать с целью обязательного использования.

The results of studies of quality maize hybrid seeds and self-pollinated lines taken from the parties with the same laboratory germination are presented. A significant difference of the seeds under the terms of its power of growth, germination after cold and field let germinate, also yield even within a category of the seed condition is determined. The correlation method of the seeds cold germination which correlation level amounts to 0,72-0,81 in comparison with its field germination is recommended for the establishment of different quality. A method is proposed to use in the system of internal quality control of quality seeds, as well as to standardize obligatory use. 